\title{
MENYELAMI METODE PENDIDIKAN HUMANISTIK SOSAKU KOBAYASHI DALAM NOVEL TOTTO CHAN: THE LITTLE GIRL AT THE WINDOW KARYA TETSUKO KUROYANAGI
}

\author{
Apri Damai Sagita Krissandi*(1), Kelik Agung Cahya Setiawan (2)
}

(1) Program Studi PGSD Universitas Sanata Dharma Yogyakarta

(2) Program Studi Pendidikan Bahasa dan Sastra Indonesia Universitas Negeri Yogyakarta

*apridamai@usd.ac.id

\begin{abstract}
Abstrak
Penelitian ini bertujuan untuk mendeskripsikan metode pendidikan humanistik yang diterapkan oleh Sosaku Kobayashi di sekolah Tomoe Gakuen dalam novel Totto Chan: The Litle Girl At The Window karya Tetsuko Kuroyanagi. Metode yang digunakan dalam penelitian ini adalah deskriptif. Berdasarkan analisis terhadap kajian mengenai novel Totto Chan: The Litle Girl At The Window karya Tetsuko Kuroyanagi, maka dapat disimpulkan bahwa metode pendidikan yang diterapkan oleh Sosaku Kobayashi di sekolah Tomoe Gakuen merupakan metode pendidikan humanistik untuk menciptakan kepribadian yang autentik seperti (1) memperkuat kepercayaan diri peserta didik dalam memberikan makna kehidupan, (2) membuka jalan untuk mengembangkan kemampuan diri, berdasarkan kebebasan dan tanggung jawab, (3) membimbing peserta didik untuk menemukan kehidupan dengan motivasi diri dan keinginan untuk menjadi lebih, (4) mengembangkan cara pandang secara original dan berekspresi sesuai dengan diri peserta didik. Keempat hal tersebut dapat dilihat melalui kegiatan pembelajaran di dalam kelas, kegiatan pembelajaran di luar kelas, peraturan sekolah, serta peran pendidik dalam pembelajaran.
\end{abstract}

\section{Kata kunci: Pendidikan, Totto Chan, Humanisme, Pendidikan Humanistik}

\begin{abstract}
(Understanding The Education Method Of Sasoko Kobayashi In Novel Totto Chan: The Little Girl At The Window By Tetsuko Kuroyanagi) This study was aimed to describe the humastic educational method applied by Sosaku Kobayashi at Tomoe Gakuen school in Totto Chan's novel: The Litle Girl At The Window by Tetsuko Kuroyanagi. The method used in this research was descriptive. Based on the analysis of the study of Totto Chan's novel: The Litle Girl At The Window by Tetsuko Kuroyanagi, it can be concluded that the educational method applied by Sosaku Kobayashi at Tomoe Gakuen school was a method of humanistic education including ways to create authentic personality such as (1) strengthen students' confidence in giving meaning to life (2) paving the way for self-development, based on freedom and responsibility, (3) guiding learners to find life with self-motivation and desire to become more, (4) developing a worldview in a way original and expression in accordance with the students themselves. The four things can be seen through the learning activities in the classroom, learning activities outside the classroom, school rules, and the role of educators in learning.
\end{abstract}

Keywords: Education, Totto Chan, Humanism, Humanistic Education 


\section{PENDAHULUAN}

Novel Totto Chan: The Litle Girl At The Window karya Tetsuko Kuroyanagi, merupakan novel autobiografi. Novel Totto Chan: The Litle Girl At The Window karya Tetsuko Kuroyanagi, merupakan novel yang terbit pertama ditahun 1981 di negara Jepang. Novel ini diterbitkan di Indonesia pada tahun 2008 oleh PT Gramedia Pustaka Utama. Novel Totto Chan: The Litle Girl At The Window karya Tetsuko Kuroyanagi bercerita mengenai kehidupan seorang anak perempuan yang tidak lain adalah Tetsuko yang diwujudkan dengan tokoh Totto-Chan. Totto-Chan merupakan anak yang memiliki permasalahan mengenai keingintahuannya yang besar yang kadang menimbulkan kegaduhan dalam kelas. Totto-Chan dianggap sebagai anak yang nakal oleh guru kelasnya hingga dikeluarkan pada hari pertama Totto-Chan bersekolah. Namun setelah Totto-Chan masuk di sekolah yang bernama Tomoe Gakuen yang dipimpin oleh kepala sekolah bernama Sosaku Kobayashi, Totto-Chan mengalami perubahan yang besar dalam hidupnya. Tome Gakuen merupakan sekolah yang dipimpin dan dibangun oleh Sosaku Kobayashi dengan metode pembelajaran yang berbeda dengan sekolah lain yaitu metode pembelajaran yang mengutamakan kebebasan dan kemandirian.

Sosaku Kobayashi digambarkan sebagai sosok seorang pendidik yang hangat serta sangat menghargai peserta didik. Sosaku Kobayashi mempunyai pendapat jika dalam mendidik anak haruslah mengutamakan kepercayaan serta selalu memberi nasihat dan pujian kepada peserta didik untuk menumbuhkan rasa percaya diri, tanggung jawab, simpati terhadap orang lain. Selain itu Sosaku Kobayashi memberikan metode pembelajaran dengan menumbuhkan karakter anak untuk mendekatkan peserta didik kepada alam karena alam merupakan sumber dari berbagai ilmu dan pengetahuan. Secara tidak langsung Sosaku Kobayashi mengarahkan pada peserta didik sesuai dengan perkembangan dan tanpa paksaan.

Novel Totto Chan: The Litle Girl At The Window telah banyak menjadi bahan kajian penelitian karena lekatnya unsur pendidikan di dalamnya. Seperti penelitian yang dilakukan oleh Gofur yang menggali nilai-nilai pendidikan dalam novel Totto Chan: The Litle Girl At The Window. Penelitian ini menemukan 52 nilai pendidikan yang terkandung dalam novel, dan 28 nilai pendidikan berdasarkan perspektif Paulo Freire. Nilai-nilai itu dibagi menjadi 6 poin: pendidikan yang membebaskan, pedagogi yang tertindas, pendidikan dialogis, konsep coenscientization, pendidikan kontekstual dan pendidikan kritis (Ghofur, 2017). Penelitian ini sangat baik dalam menggali nilai-nilai di dalam novel tersebut, tetapi tidak mendalam pada nilai-nilai yang dimaksud. Penelitian ini fokus pada generalisasi nilai-nilai yang muncul tanpa membahas secara mendalam nilai-nilai tersebut.

Penelitian yang bernuansa pendidikan juga juga pernah dilakukan oleh Hastuti yang mengkaji bagaimana Kobayashi dalam membimbing mental murid-muridnya. Kobayashi berusaha menumbuhkan rasa percaya diri, ketegaran, dan rasa menghargai orang lain, seperti apapun keadaan orang itu (Hastuti, 2019). Penelitian ini sangat baik menjelaskan guru Kobayashi dalam mendampingi murid-muridnya, penulis tertarik untuk melengkapi penelitian ini dengan melihat metode pembelajaran tersebut dalam teori pendidikan.

Penulis akan melihat lebih dalam metode pendidikan yang dilakukan oleh Kobayashi dalam sudut pandang pendidikan humanistik. Humanisme merupakan gerakan kultural yang muncul dan mampu memberikan pandangan berbeda mengenai konsep pendidikan. Pada umumnya, yang 
Izumi, Volume 8 No 1, 2019

e-ISSN: 2502-3535 p-ISSN: 2338-249X

Tersedia online di http://ejournal.undip.ac.id/index.php/izumi

menjadi dasar untuk dijadikan acuan para pemikir pendidikan humanistik adalah potensi manusia yang harus digali sedalam-dalamnya dan seluas-luasnya tanpa dibatasi dengan berbagai dogma yang mengekang rasionalitas manusia. Seperti yang dikatakan oleh (Aloni, 2013).

"Humanistic education is characterized by general and multifaceted cultivation of the personality of those being educated, in a climate of intellectual freedom and respect for human dignity, towards the best and highest life of which they are capable in there fundamental domains of life: as individual who harmoniously and authentically realize their potential, as involved and responsible citizens in a democracy, and as human beings who enrich and perfect themselves through active engagement with the collective achivement of human culture."

Pengertian yang diungkapkan di atas memberikan gambaran bahwa pendidikan humanistik merupakan usaha dalam membentuk manusia yang memiliki aspek dimensional dengan kondisi belajar dengan penuh kebebasan dan penghargaan atas martabat manusia. Pendidikan humanistik adalah pendidikan yang memfokuskan pada peran peserta didik, yaitu pola pendidikan yang menghargai keragaman karakteristik peserta didik dan upaya untuk mengembangkan setiap potensi peserta didik secara optimal sehingga peserta didik dapat memiliki kecakapan dalam hidup selaras dengan kondisi pribadi dan lingkungan (Alauddin, 2015).

Salah satu tujuan dari pendidikan yang humanistik adalah menciptakan manusia yang autentik. Kepribadian yang autentik merujuk pada kemampuan manusia dalam berpikir bukan hanya pada dirinya melainkan juga berpikir bagaimana menjadi dirinya secara utuh. Kepribadian yang autentik ini akan membimbing manusia dalam menaruh perhatian, empati, eksistensi diri (Alauddin, 2015).

Inti dari pendidikan adalah untuk menciptakan kepribadian autentik dalam perjuangan untuk menghidupkan kembali dan merekonstruksi perasaan ke "aku"an dari pembelajaran. Adapun cara untuk menciptakankepribadian autentik dapat dilakukan dengan (1) memperkuat kepercayaan diri peserta didik dalam memberikan makna kehidupan, (2) membuka jalan untuk mengembangkan kemampuan diri, berdasarkan kebebasan dan tanggung jawab, (3) membimbing peserta didik untuk menemukan kehidupan dengan motivasi diri dan keinginan untuk menjadi lebih, (4) mengembangkan cara pandang secara original dan berekspresi sesuai dengan diri peserta didik (Aloni, 2013).

Berdasarkan uraian di atas, penulis tertarik untuk mengkaji novel Totto Chan: The Litle Girl At The Window karya Tetsuko Kuroyanagi karena dalam novel ini terdapat banyak metode pendidikan yang dapat dijadikan acuan dalam proses pembelajaran dan memfokuskan makalah ini mengenai metode pendidikan humanistik yang diterapkan oleh Sosaku Kobayashi di sekolah Tomoe Gakuen untuk membentuk kualitas karakter peserta didik khususnya pada tokoh Totto-chan. Penulis menjadikan novel Totto Chan: The Litle Girl At The Window karya Tetsuko Kuroyanagi sebagai bahan kajian dengan judul "Menyelami Metode Pendidikan Tokoh Kobayashi dalam Novel Totto Chan: The Little Girl At The Window Karya Tetsuko Kuroyanagi"

\section{METODE}

Penelitian ini merupakan penelitian deskriptif yang bertujuan untuk mendeskripsikan metode pendidikan yang dilakukan oleh Sasoko Kobayashi (tokoh guru) dalam novel Totto Chan. Teknik pengumpulan data yang digunakan dalam penelitian ini adalah studi dokumentasi. 
Untuk menetapkan keabsahan data diperlukan kriteria pemeriksaan data berupa kriteria derajat kepercayaan. Hal ini dilakukan untuk menjaga kredibilitas hasil penelitian yang dilakukan. Validasi yang digunakan untuk menjaga kredibilitas ini adalah trianggulasi. Triangulasi merupakan teknik pemeriksaan keabsahan data yang memanfaatkan sesuatu yang lain di luar data itu untuk keperluan pengecekan atau sebagai pembanding terhadap data itu. Terdapat empat (4) macam triangulasi sebagai teknik pemeriksaan yang memanfaatkan penggunaan, sumber, metode, penyidik, dan teori (Moleong, 2014). Dalam hal ini peneliti menggunakan teknik triangulasi dengan metode, yang berarti membandingkan dan mengecek suatu informasi yang diperoleh melalui metode yang berbeda. Analisis yang dilakukan dalam penelitian ini terdiri dari tiga jalur kegiatan yang berjalan secara simultan. Ketiga jalur tersebut meliputi: (1) reduksi data, yakni proses pemilihan, pemusatan, perhatian pada penyederhanaan, pengabstrakan, dan transformasi data kasar yang muncul dari catatan-catatan dokumentasi; (2) penyajian data, yakni penyajian informasi yang telah tersusun yang kemungkinan memberikan penarikan kesimpulan; dan (3) penarikan kesimpulan/verifikasi, dalam kegiatan ini peneliti mencari arti temuan, kode-kode, mencatat urutan, dan pola-pola dari permulaan pengumpulan data.

\section{HASIL DAN PEMBAHASAN \\ Hasil}

\section{a. Tokoh Penokohan}

Tokoh dalam novel Totto Chan: The Litle Girl At The Window karya Tetsuko Kuroyanagi mempunyai tokoh penting yang menentukan alur dalam novel tersebut, misalnya Sosaku Kobayashi, Totto-Chan,Takashi-kun, mama TottoChan, Oe-kun. Berkaitan dengan kajian mengenai proses pendidikan yang diterapkan oleh Sosaku Kobayashi dalam novel, maka Tokoh Sosaku Kobayashidan
danTotto-chan dijadikan sebagai objek utama kajian. Selain karena kedua tokoh ini begitu dominan juga karena melalui tokoh ini,proses pendidikan serta dampak dalam proses pendidikan yang dilakukan begitu terlihat. Sedangkan Takashi-kun, mama, oe-kun merupakan tokoh pendukung dalam novel tersebut.

a) Sosaku Kobayashi

Sosaku Kobayashi merupakan pendiri, pemilik, serta kepala sekolah Tomoe Gakuen. Hal ini terdapat dalam kutipan

"Sekolah seperti apa yang akan kita bangun kembali?" (Kuroyanagi, 2008).

Sasoko Kobayashi merupakan seorang laki-lakiyang memiliki rambut tipis dengan beberapa gigi dengan wajah yang segar. Sasoko Kobayashi memiliki badan yang tegap namun tidak terlalu tinggi. Hal ini dapat dilihat dalam kutipan berikut ini.

"Pria yang ada di kantor itu bangkit berdri dari kursinya. Rambutnya tipis, beberapa giginya sudah tanggal, tapi "wajahnya terlihat segar. Meskipun perawakanya tidak terlalu tinggi, bahu dan lenganya tampak tegap" (Kuroyanagi, 2008).

Kepala Sekolah Sasoko Kobayashi juga merupakan seorang pendidik yang memiliki pribadi yang hangat, ramah, serta sangat menghargai peserta didik. Indikasi tersebut dapat dilihat dari kutipan berikut ini.

"Belum pernah ada orang yang mau mendengarkan dia sampai berjam-jam seperti kepala sekolah. Lebih dari itu, kepala sekolah sama sekali tidak menguap ataupun tampak bosan. Dia selalu tampak tertarik pada apa yang diceritakan Toto-Chan" (Kuroyanagi, 2008). 
Izumi, Volume 8 No 1, 2019

e-ISSN: 2502-3535 p-ISSN: 2338-249X

Tersedia online di http://ejournal.undip.ac.id/index.php/izumi

"Bayangkan Toto-Chan dan mama sampai di sekolah jam delapan tapi ketika dia selesai bercerita, dan menyatakan dia murid sekolah itu, pria itu melihat jam sakunya dan berkata, "ah, sudah waktunya makan siang." Jadi kepala sekolah sudah mendengarkan cerita Toto-Chan lebih dari empat jam penuh!" (Kuroyanagi, 2008).

Kutipan di atas menjelaskan mengenai sosok Sasoko Kobayashi sangat menghargai peserta didik. Ini dibuktikan dengan dia mendengarkan cerita yang diutarakan oleh Totto-Chan hampir empat jam tanpa sedikitpun merasa ngantuk ataupun bosan dalam mendengarkan cerita yang diutarakan oleh Totto-Chan.

Watak tokoh dalam karya sastra dibedakan menjadi tokoh antagonis serta protagonis. Tokoh protagonis adalah tokoh yang wataknya disukai pembaca. Tokoh ini memiliki pribadi yang baik dan positif. Sedangkan tokoh antagonis merupakan tokoh yang wataknya tidak disukai pembaca (Siswanto, 2008). Tokoh Sasoku Kobayashi tergolong pada tokoh protagonis yang memiliki karakter yang baik dan selalu menghargai kepada peserta didik.

b) Totto-chan

Tetsuko Kuroyanagi merupakan nama panjang dari Totto-chan. Totto-chan merupakan anak pertama dalam keluarga. Ayah Totto-chan adalah seorang pemain biola profesional dan ibunya adalah ibu rumah tangga yang bekerja untuk mengelola keluarga. Totto-Chan memiliki peliharaan seekor anjing yang diberinama Rocky. Perkembangan kepribadian tokoh dapat dibedakan menjadi dua yaitu tokoh statis dan tokoh dinamis. Tokoh Statis merupakan tokoh yang memiliki kepribadian yang tetap, sedangkan tokoh dinamis merupakan tokoh yang memiliki kepribadian yang berkembang (Aminudin, 2012).
Pada novel Totto Chan: The Litle Girl At The Window, Tokoh Totto-Chan memiliki watak yang dinamis. Hal ini diperlihatkan melalui alur cerita yang ada dalam novel tersebut. Totto-chan yang awalnya dianggap seorang anak yang nakal karena rasa keingintahuannya yang besar kemudian berubah kepribadiannya menjadi pribadi yang lebih baik melalui proses pendidikan yang diterapkan oleh Sosako Kobayashi di sekolah Tomoe Gakuen. Berikut kutipan yang diambil dari percakapan guru kelas Totto-chan dengan mama yang menunjukkan tingkah laku Toto-chan yang dianggap nakal oleh gurunya.

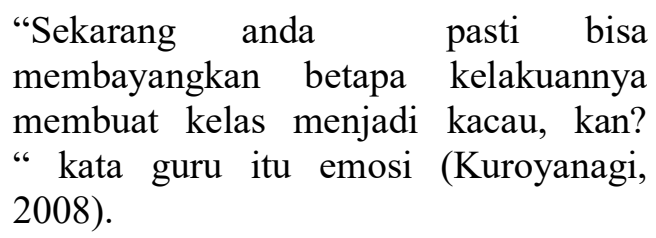

Berdasarkan kutipan di atas, dapat dilihat bahwa Totto-chan dianggap sebagai anak yang nakal karena memiliki kelakukan yang berbeda dengan anak lain di sekolah. Hampir setiap waktu, di sekolahnya yang lama Totto-chan selalu membuat keributan dikelas dengan tingkah lakunya. Sebenarnya, Totto-chan merupakan anak yang baik. Berikut kutipan yang menunjukan bahwa Totto-chan adalah anak yang baik.

Dia baik hati kepada siapa saja khususnya kepada kawan-kawanya yang punya cacat tubuh. Ia selalu membela mereka. Jika anak dari sekolah lain mengatai kawan-kawanya yang cacat, ia berani berkelahi dengan yang jahat, walaupun akhirnya ia menangis (Kuroyanagi, 2008: 187).

Totto-chan juga memiliki watak yang periang dan penuh semangat apalagi ketika dia mengetahui ada hal baru yang belum dia tahu. Berikut kutipan yang menunjukkan bahwa Totto-chan adalah anak yang penuh semangat dan periang. 
Sesaat Kemudian, Totto-chan menjerit kegirangan lalu berlari cepat ke arah sekolah kereta. Dia menoleh ke belakang lalu berteriak kepada mama, "Ayo, ma, cepat! Cepat! Ayo kita naik kereta tidak bergerak itu!" (Kuroyanagi, 2008: 21).

c) Mama

Mama merupakan seorang ibu yang sabar, bijaksana dan suka bercanda. Berikut kutipan yang memperlihatkan bahwa mama adalah tokoh yang sabar, bijaksana dan suka bercanda.

"Mama memiliki sifat yang sangat sabar dan suka bercanda." (Kuroyanagi, 2008: 22).

Mama tidak bilang kepada Totto-chan bahwa dia dikeluarkan dari sekolah. Dia tahu, Totto-chan akan mengerti mengapa dia dianggap telah berbuat salah dan mama tidak ingin putrinya menderita tekanan batin, jadi diputuskannya untuk tidak memberitahu Totto-chan sampai dia dewasa. (Kuroyanagi, 2008:18).

d) Yasuaki Yamamoto

Yasuaki Yamamoto merupakan siswa yang pintar dan ramah namun memiliki keterbatasan fisik karena terkena penyakit polio. Berikut kutipan yang menggambarkan tokoh Yasuaki Yamamoto.

Totto-chan berhenti memandang sekelilingnya dan dengan tangan menopang dagu, dia menatap punggung anak laki-laki yang berjalan ke depan itu. anak itu menyeret kakinya, seluruh tubuhnya bergoyang aneh. Mula-mula Totto-chan mengira anak itu sengaja melakukannya, tapi lalu segera tahu bahwa itu bukan alasanya. Ketika anak itu sudah duduk di bangku di belakangnya, dia membutuhkan waktu lama dari pada anak lain untuk duduk. Totto-chan memutar badan dan bertanya, "mengapa kau jalan seperti itu?" Anak itu menjawab lirih, dengan suara lembut yang terdengar cerdas, "aku kena polio.” (Kuroyanagi, 2008: 39)

e) Takashi-kun

Takashi-kun merupakan murid pindahan dari Osaka yang pindah di sekolah Tomoe Gakuen. Takashi-kun merupakan siswa yang memiliki kekurangan pada pertumbuhannya yang tidak sempurna sehingga menimbulkan rasa ketidak percayaan diri. Hal tersebut dapat dilihat dari kedua kutipan di bawah ini.

Tapi Takashi, meskipun laki-laki, tubuhnya jauh lebih kecil dari mereka. Lengan dan tungkai kakinya sangat pendek. Tangannya yang memegangi topiya juga pendek. Tapi bahunya kekar. Anak itu berdiri dengan wajah muram (Kuroyanagi, 2008:115).

\section{f) Oe-kun}

Oe-kun merupakan anak laki-laki yang mempunyai tubuh gemuk, dan mempunyai watak yang dinamis. Hal ini diperlihatkan dalam beberapa kutipan cerita yang ada dalam novel tersebut. Oe-kun awalnya merupakan anak yang nakal dan tidak sopan kepada anak perempuan. Hal ini terdapat dalam beberapa kutipan berikut.

Badan Oe dua kali lebih besar daripada bada Tottot-chan yang kurus. Oe anak paling besar dan gemuk dikelas (Kuriyanagi, 2008:157).

Mendengar rambutnya dibandingkan dengan tali pegangan saja sudah menyakitkan apalagi kemudian ia diseret di tanah. Tapi ketika Oe mencoba menariknya berdiri dengan menjambak kepangnya sambil berteriak "Ayo tarik! Tarik!" (Kuroyanagi. 2008: 158) 
Izumi, Volume 8 No 1, 2019

e-ISSN: 2502-3535 p-ISSN: 2338-249X

Tersedia online di http://ejournal.undip.ac.id/index.php/izumi

Melalui pendekatan yang dilakukan oleh Sosaku Kobayashi sifat yang ada pada Oekun berubah menjadi anak yang sopan hingga akhirnya Totto-chan mendapatkan pemahaman bahwa anak laki-laki harus bersifat sopan dengan anak perempuan. Kutipan yang menunjukkan perubahan Oekun ditunjukkan melalui kutipan berikut.

Maaf, tadi aku menarik-narik rambutmu," kata Oe dengan suara bernada datar.

Kata kepala sekolah aku harus bersikap manis pada anak perempuan (Kuroyanagi, 2008: 159).

\section{b. Latar Tempat}

a) Letak Sekolah Tomoe Gakuen

Tomoe Gakuen terletak di Tokyo tenggara, tiga menit jalan kaki dari Stasiun Jiyugaoka di jalur Tokyo (Kuroyanagi, 2008: 250).

b) Kelas Tomoe Gakuen

Kelas yang dimiliki oleh sekolah Tomoe Gakuen bukan merupakan ruang kelas dengan gedung yang terbuat dengan menggunakan pilar-pilar beton melainkan dengan menggunakan gerbong kereta.

Sekolah itu menggunakan enam gerbong kereta yang sudah tidak terpakai (Kuroyonagi, 2008: 20).

\section{c. Latar Waktu}

Sekolah Tomoe Gakuen dibangun di tahun 1937 yang masuk pasca restori meiji dan berakhir di tahun 1945. Tomoe Gakuen terbakar dan berakhir karena perang dunia II. Berikut kutipan yang menunjukkan latar waktu sekolah Tomoe Gakuen.

Mr Kobayashi belajar bertahun-tahun sebelum mendirikan Tomoe Gakuen di tahun 1937. Sekolah itu terbakar habis tahun 1945, jadi masa hidupnya singkat sekali (Kuroyanagi. 2008: 251).
Banyak bom yang dijatuhkan pesawat pembom B29 menimpa gerbonggerbong kereta api yang berfungsi sebagai kelas (Kuroyanagi, 2008: 247).

\section{d. Latar Sosial}

Reformasi pendidikan di Jepang dimulai pada tahun 1868 dengan ditandai kebijakan dari kaisar Jepang yang populer dengan sebutanRestorasi Meiji. Novel ini merupakan gambaran mengenai pendidikan pasca Restorasi Meiji tepatnya di tahun 1930 sampai dengan 1945. Di tahun tersebut negara Jepangsudah pada posisi reformasi pendidikan secara menyeluruh termasuk memasukkan pendidikan barat kedalam sistem pendidikan (Andari, 2011).

Walaupun sistem pendidikan yang diterapkan Mr. Kobayashi sungguh unik, sebenarnya dia banyak dipengaruhi gagasan-gagasan dari Eropa dan negaranegara lain (Kuroyanagi, 2008: 149)

\section{e. Alur}

Alur merupakan rangkaian peristiwaperistiwa dalam sebuah cerita yang terhubung berdasarkan kualitas yang mencakup perubahan sikap karakter, kilasan-kilasan pandangan, keputusankeputusan dan segala pengubah dalam diri tokoh (Stanton, 2007). Alur sebagai jalinan peristiwa dalam karya sastra untuk mencapai efek tertentu (Siswanto, 2008). Maka dari pendapat ahli tersebut, dapat disimpulkan bahwa alur merupakan rangkaian peristiwa-peristiwa dalam cerita yang terhubung karena adanya sebab akibat.

Novel Totto Chan: The Litle Girl At The Window karya Tetsuko Kuroyanagi menggunakan alur maju karena dimulai dari tahap awal hingga akhir. Awal dari novel ini ditandai dengan tokoh Totto-chan yang dianggap anak nakal karena sering membuat ulah di kelas hingga akhirnya dia dikeluarkan di hari pertama dia bersekolah. Selanjutnya tokoh mama memindahkan 
Totto-chan ke sekolah yang bernama Tomoe Gakuen. Tomoe Gakuen yang dipimpin oleh kepala sekolah Sosaku Kobayashi yang menerapkan metode pendidikan yang berbeda dengan sekolah lain di Jepang pada saat itu. Metode pendidikan kepala sekolah Tomoe Gakuen tidak hanya memfokuskan kepada pendidikan formal, namun juga pada pendidikan karakter. Hingga akhirnya metode tersebut berhasil mendidik semua peserta didik salah satunya adalah Tottochan menjadi pribadi yang autentik. Walaupun sekolah Tomoe Gakuen belum sempat berkembang karena terbakar akibat perang.

\section{f. Tema}

Tema merupakan pandangan hidup tertentu atau perasaan tertentu mengenai kehidupan atau rangkaian nilai-nilai tertentu yang membangun dasar atau ide utama suatu karya sastra (Tagiran, 2008). Tema merupakan ide yang mendasari suatu cerita sehinga berperan sebagai pangkal tolak pengarang dalam memaparkan karya fiksi (Aminudin, 2012). Tema adalah suatu gagasan dasar umum yang menopang sebuah karya sastra (Siswanto, 2008). Dari pendapat ahli di atas, tema dapat dikatakan sebagai dasar pikiran dalam sebuah cerita yang hendak disampaikan pengarang melalui jalan cerita.

Berdasarkan isi cerita, tema novel Totto Chan: The Litle Girl At The Window karya Tetsuko Kuroyanagi mengenai proses pendidikan yang diterapkan oleh Sosaku Kobayashi di sekolah Tomoe gakuen serta keberhasilanya dalam mendidik dan membentuk peserta didik.

\section{Pembahasan}

\section{a. Kegiatan Belajar Tomoe Gakuen di} Luar Kelas

Sekolah Tome Gakuen merupakan sekolah yang unik dalam menerapkan kegiatan pembelajaran. Kegiatan pembelajaran yang dilakukan di sekolah ini adalah dengan mengkombinasikan materi pembelajaran melalui kegiatan yang berhubungan dengan alam atau bisa dikatakan metode pendidikan yang digunakan di Tomoe Gakuen adalah menyeimbangkan teori dan praktik dalam kegiatan pembelajaran di alam. Selain itu, pemberian materi tidak hanya pada waktu di kelas saja, namun setiap kegiatan sekolah yang dilakukan merupakan pembelajaran. Metode tersebut digunakan untuk mengembangkan potensi dan kepribadian peserta didik melalui pengamatan di alam. Proses pembelajaran yang ada di Tomoe Gakuen pun dibuat agar peserta didik merasakan bahwa belajar itu menyenangkan. Hal ini dilakukan untuk menghindarkan peserta didik dari tekanan dalam pembelajaran. Indikasi yang menyangkut mengenai proses pembelajaran dalam kegiatan di luar kelas yang mengkombinasikan materi pembelajaran melalui kegiatan yang berhubungan dengan alam.

Sekarang tiba waktunya untuk "sesuatu dari laut dan sesuatu dari pegunungan," (Kuroyonagi, 2008: 41).

Pada kutipan di atas, Sosaku Kobayashi bermaksud untuk menjelaskan mengenai makanan yang mengandung gizi seimbang melalui petunjuk yang dilakukan dalam kegiatan makan siang. Selain hal tersebut metode pendidikan diluar kelas yang dilakuan melalui kegiatan berjalan-jalan di alam. Hal ini dapat dilihat dari kutipan.

Setelah berjalan-jalan kira-kira sepuluh menit, guru berhenti. Dia menunjuk beberapa kuntum bunga berwarna kuning dan berkata, "lihat bunga sesawi itu. kalian tahu mengapa bunga-bunga mekar?" dia menjelaskan tentang putik dan benar sari sementara anak-anak berjongkok di pinggir jalan dan mengamati bunga-bunga itu. (Kuroyanagi, 2008: 49). 
Izumi, Volume 8 No 1, 2019

e-ISSN: 2502-3535 p-ISSN: 2338-249X

Tersedia online di http://ejournal.undip.ac.id/index.php/izumi

Dari kutipan tersebut secara tidak langsung anak diajak belajar tentang biologi yang dikemas dengan acara bebas dan santai. Selain memberikan materi pelajaran, Sosaku Kobayashi juga memberikan pemahaman untuk selalu menghargai kepada setiap manusia walaupun mereka mempunyai kekurangan. Hal tersebut dapat dilihat dari kegiatan olah raga berenang.

Anak yang kurus, gendut, laki-laki, perempuan. Semua tertawa, berteriak, bermain ciprat-cipratan dalam pakaian yang mereka kenakan waktu mereka dilahirkan (kuroyanagi, 2008: 72).

Dari kutipan di atas, Sosaku Kobayashi mencoba memberikan pemahaman kepada setiap anak bahwa setiap manusia itu istimewa. Selain itu tujuandari kegiatan ini adalah untuk menghilangkan rasa rendah diri peserta didik khususnya pada kekurangan fisik. Hal ini dibuktikan pada kutipan berikut ini.

Mula-mula anak-anak yang cacat merasa malu, tapi perasaan itu segera hilang dan akhirnya mereka benar-benar berhasil menghilangkan rasa malunya. (Kuroyanagi, 2008: 73).

Menyeimbangkan teori dan praktik dalam kegiatan pembelajaran di alam ini membuat peserta didik mengerti dan memahami pelajaran dengan cepat karena di umur tersebut anak masih pada masa usia 7-12 tahun anak maasuk dalam operasional kongkrit, tanpa objek fisik di hadapan mereka, anak-anak pada tahap operasional kongkrit masih mengalamikesulitan besar dalam menyelesaikan tugas-tugas logika. maka dari itu metode yang dilakukan disekolah Tomoe Gakuen khususnya anak kelas 1 menggunakan metode yang menyeimbangkan teori dan praktik.

\section{b. Kegiatan Belajar Tomoe Gakuen di Dalam Kelas}

Pada hakikatnya pembelajaran yang ada di Tomoe Gakuen khususnya di kelas menggunakan metode pembelajaran yang bebas dan mandiri. Metode pembelajaran bebas di sini adalah pembelajaran yang mengutamakan minat siswa dalam belajar. Guru dalam metode yang ada di Tomoe Gakuen berperan sebagai fasilitator. Fasilitator yang dimaksud adalah guru memberikan kemudahan bagi peserta didik dalam proses pembelajaran. Hal ini dapat dilihat melalui kutipan di bawah ini.

Di awal jam pelajaran pertama, guru membuat daftar semua soal dan pertanyaan mengenai hal-hal yang akan diajarkan hari ini. Kemudian guru berkata, "Sekarang, mulailah dengan salah satu dari ini. Pilih yang kalian suka." (Kuroyanagi, 2008: 37).

Guru akan mendatangi murid jika diminta dan menjelaskan setiap hal sampai anak itu benar-benar mengerti. Kemudian mereka diberikan latihanlatihan lain untuk dikerjakan sendiri (Kuroyanagi, 2008: 38).

Dari kedua kutipan di atas, dapat disimpulkan bahwa metode pendidikan yang dilakukan oleh Sosaku Kobayashi di sekolah Tomoe Gakuen adalah metode bebas dan mandiri. Hal ini dilakukan sebagai salah satu cara untuk membentuk kepribadian yang autentik

\section{c. Peraturan Sekolah}

Peraturan sekolah pada umumnya menjadi momok yang menakutkan bagi peserta didik karena hanya berisi peraturanperaturan yang mengikat. Jika melanggar aturan tersebut maka hukumanlah yang didapat. Berbeda dengan Sekolah Tomoe Gakuen, kebijakan kepala sekolah Sosaku Kobayashi tidak memberikan peraturanperaturan yang mengikat dan penuh tekanan pada peserta didik. Hal ini dapat dilihat dari beberapa kutipan yang ada dalam novel. 
a) Peraturan tempat duduk

Tomoe Gakuen, peserta didik diperbolehkan untuk bebas memilih tempat duduk sesuka hati tanpa ada peraturan yang mengharuskan duduk diposisi yang samaselama satu minggu, satu bulan, bahkan satu tahun.

Di sekolah lain setiap anak diberi satu bangku tetap. Tapi disini mereka boleh duduk sesuka hati, dimana saja, kapan saja (Kuroyanagi, 2008: 37).

Setelah lama berpikir dan memandang sekeliling bai-baik, Totto-chan memutuskan duduk di samping anak perempuan yang datang sesudahnya tadi pagi karena anak itu mengenakan rok pindafore (Kuroyanagi, 2008: 37).

Pada kutipan di atas dapat disimpulkan bahwa peserta didik tidak dipaksa untuk duduk disuatu tempat, namun peserta didik diberi kebebasan sesuai dengan keinginan mereka. Hal ini digunakan untuk memotivasi belajar siswa karena tempat duduk yang bebas dapat mengurangi kebosanan dalam pembelajaran.

\section{b) Peraturan Berpakaian}

Sekolah pada umumnya memang mewajibkan peserta didik untuk menggunakan pakaian seragam. Namun berbeda dengan di Tomoe Gakuen, sekolah ini tidak memiliki aturan untuk mengenakan baju sragam. Namun aturan yang digunakan adalah untuk menggunakan pakaian usang sebagai pakaian sekolah.

Kepala sekolah selalu meminta para orang tua agar menyuruh anak-anak mereka mengenakan pakaian paling usang untuk bersekolah di Tome Gakuen (Kuroyanagi, 2008: 111).

Alasan kepala sekolah Sasoko Kobayashi menerapkan aturan tersebut karena sangat mengerti perkembangan anak, bahwa anak di umur tersebut masih masuk dalam dunia bermain. Jika memakai pakaian bagus maka kemungkinan anak akan takut dimarahi akibat mengotori pakaian mereka, atau ragu-ragu bergabung mengikuti suatu permainan karena cemas baju mereka sobek dan berdampak pada tidak merasakan dunia anak-anak yang masih masuk dalam dunia bermain.

\section{d. Peran Pendidik dalam Pembelajaran}

a) Sosaku Kobayashi: Pendidik yang Ramah dan Menyenangkan

Suasana belajar yang diciptakan guru sangat berpengaruh kepada peserta didik. Begitu juga saat pendidik melakukan sesuatu yang salah dalam menghadapi peserta didik. Misalnya guru melakukan sindirian kepada peserta didik yang melakukan kesalahan. Sindirian tersebut akan mempunyai dampak negatif kepada peserta didik. Dampak yang paling dekat adalah peserta didik merasa dirinya ditekan oleh kata-kata sindiran tersebut

Jika pendidik menghadapi peserta didik dengan tajam, sindiran, kebencian, dan antipati, akan menimbulkan pengaruh negatif pada anak dan menyesakan hari. Sebaliknya jika pendidik merupakan orang yang ramah, gembira, menyenangkan akan memberi dampak positif dalam pembelajaran. Sosako Kobayashi adalah sosok yang ramah. Hal ini dapat dilihat dari kutipan berikut.

Totto-chan belum menemukan dompetnya. Gundukan berbau busuk semakin tinggi. Kepala sekolah datang lagi. "kau sudah menemukan dompetmu? Tanyanya. "belum," jawab Totto-chan dari tengah-tengah gundukan. Keringat berleleran dan pipinya memerah. Kepala sekolah mendekat dan berkata ramah, "kau akan mengembalikan semuanya kalau sudah selesai kan?" (Kuroyanagi, 2008: 56).

Kutipan di atas adalah salah satu percakapan kepala sekolah dengan Totto- 
chan yang sedang mencari dompetnya karena terjatuh di kakus. Hal ini bermula ketikaTotto-chan mengintip lubang di kakus dan dompetnya akhirnya terjatuh. Totto-chan mencoba mencarinya di lubang pembuangan yang penuh dengan kotoran. Diceritakan Totto-chan membongkar tempat pembuangan kotoran untuk mencari dompetnya yang terjatuh di kakus. Kondisi Totto-chan penuh dengan kotoran karena mengeluarkan kotoran yang ada disapiteng membuat bau busuk menyebar diseluruh halaman. Kebanyakan orang dewasa, jika mendapati Totto-chan dalam situasi seperti itu, akan bereaksi dan memarahi Tottochan, namun kepala sekolah berbuat sebaliknya, dia tidak marah bahkan memberikan pelajaran mengenai tanggung jawab dengan mengungkapkan kata-kata yang sopan seperti kutipan di atas. Dampak dari perkataan yang sopan ini menimbulkan pemahaman mengenai tanggung jawab, yaitu segala sesuatu yang dilakukan harus dapat dipertanggungjawabkan serta tidak mengulangi kesalahan yang sama yaitu mengintip kedalam lubang kakus.

Sebagai seorang pendidik, Sosako Kobayashi merupakan sosok yang menyenangkan. Hal ini ditunjukan melalui metode-metode yang digunakan dalam pelaksanaan pembelajaran seperti pembelajaran makan bersama, masak bersama,dan berjalan-jalan sambil belajar. Salah satu kutipan yang menunjukkan bahwa Sosaku Kobayashi adalah guru yang menyenangkan.

Kejadian dipagi hari, kepala sekolah berkata kepada murid-murid,"udara tiba-tiba panas, sebaiknya aku mengisi kolam."

"asik! “ semua murid berteriak-teriak sambil meloncat-loncat. (Kuroyanagi, 2008: 70).

Dari kutipan di atas menjelaskan bahwa metode yang diberikan oleh kepala sekolah merupakan metode yang menyenangkan, terbukti dengan adanya perkataan asik yang keluar dari peserta didik mendengar perkataan atau intruksi yang diberikan oleh kepala sekolah. Dampak dari metode pendidikan yang berjalan lancar karena perasaan senang peserta didik akan berdampak pada pemahaman peserta didik terhadap materi pembelajaran.

b) Pemberian Sugesti sebagai Bentuk Motivasi

Sugesti merupakan pengaruh dari jiwa atau perbuatan seseorang sehingga mempengaruhi pikiran, perasaan, dan kemauan. Melalui sugesti positif, peserta didik secara tidak langsung akan mendapatkan suatu dorongan dalam diri yang dipengaruhi oleh sugesti tersebut (Ahmadi, 2013). Sugesti ini efektif diberikan kepada Totto-chan oleh Sosaku Kobayashi dalam membentuk karakter individu.

Tingkah laku nakal Totto-chan berubah ketika Totto-chan ditangani oleh Sosaku Kobayashi di sekolah Tomoe Gakuen melalui metode yang diterapkan di sekolah tersebut. Salah satu metode yang dilakukan Sosaku Kobayashi melalui pemberian sugesti untuk memotivasi. Berikut kutipan yang menunjukkan pemberian motivasi kepada Totto-chan.

"Kau benar-benar anak baik, kau tahu itu, kan?" itu selalu dikatakan Sosaku Kobayashi setiap kali berpapasan dengan Totto-chan. (Kuroyanagi, 2008: 187).

Melalui cara tersebut, Totto-chan dapat merasa yakin akan dirinya bahwa dia adalah anak yang baik. Perlahan dengan adanya motivasi tersebut, watak Tottochan berubah menjadi pribadi yang lebih baik.

\section{SIMPULAN}

Berdasarkan analisis terhadap kajian mengenai novel Totto Chan: The Litle Girl At The Window karya Tetsuko Kuroyanagi, 
maka dapat disimpulkan bahwa metode pendidikan yang diterapkan oleh Sosaku Kobayashi di sekolah Tomoe Gakuen merupakan metode pendidikan humanistik mencakup cara untuk menciptakan kepribadian yang autentik seperti (1) memperkuat kepercayaan diri peserta didik dalam memberikan makna kehidupan, (2) membuka jalan untuk mengembangkan kemampuan diri, berdasarkan kebebasan dan tanggung jawab, (3) membimbing peserta didik untuk menemukan kehidupan dengan motivasi diri dan keinginan untuk menjadi lebih, (4) mengembangkan cara pandang secara original dan berekspresi sesuai dengan diri peserta didik. Keempat hal tersebut dapat dilihat melalui kegiatan pembelajaran di dalam kelas, kegiatan pembelajaran di luar kelas, peraturan sekolah, serta peran pendidik dalam pembelajaran.

\section{DAFTAR PUSTAKA}

Ahmadi, A. (2013). Psikologi umum. Jakarta: Rineka Cipta.

Alauddin. (2015). Prinsip Dan Implikasi Teori Belajar Humanistik Dalam Pembelajaran. Jurnal Pendidikan 'IQRA,' 3(1), 68-73. Retrieved from https://docplayer.info/57975605Prinsip-dan-implikasi-teori-belajarhumanistik-dalam-pembelajaranalauddin-iain-palopo.html

Aloni, N. (2013). Empowering Dialogues in Humanistic Education. Educational Philosophy and Theory. Retrieved from https://doi.org/10.1111/j.14695812.2011.00789.x

Aminudin. (2012). Pengantar apresiasi karya sastra. Bandung: Sinar Baru Algesindo.

Andari, N. (2011). Nilai Pendidikan Moral Dalam Novel Madogiwa No TottoChan. 11(02), 37-51.
Ghofur, J. A. (2017). An Analysis Of Educational Values In "Totto-Chan: The Little Girl At The Window” By Tetsuko Kuroyanagi Based On Paulo Freire's Perspective. Ejournal.Stainpamekasan.Ac.Id, 1(1), 19-38. Retrieved from http://www.ejournal.stainpamekasan.a c.id/index.php/JoEE/article/view/1512

Hastuti, N. (2019). Nilai-Nilai Pendidikan Dan Pengaruhnya Terhadap Hubungan Sosial Anak Dalam Novel Totto-Chan Karya Tetsuko Kuroyanagi. Izumi, 3(2), 68. https://doi.org/10.14710/izumi.3.2.6875

Kuroyanagi, T. (2008). Totto Chan: The Litle Girl At The Window. Jakarta: PT Gramedia Pustaka Utama.

Moleong, L. (2014). Metodologi Penelitian Kualitatif. Bandung: PT. Remaja Rosdakarya.

Siswanto, W. (2008). Pengantar teori sastra. Jakarta: PT. Grasindo.

Stanton, R. (2007). Teori fiksi robert stanton. Yogyakarta: Pustaka Pelajar.

Tagiran, H. G. (2008). Membaca sebagai keterampilan berbahasa. Bandung: Angkasa. 